\title{
REVISTAMARACANAN
}

Dossiê

\section{O discurso médico-científico sobre a maconha no pós-abolição: o racismo científico como pressuposto para a emergência da ideologia proibicionista}

\section{The medical-scientific discourse on post-abolition marijuana: scientific racism as a prerequisite for the emergence of prohibitionist ideology}

\author{
Saulo Carneiro Pereira dos Santos* \\ Universidade Federal do Sul da Bahia \\ Itabuna, Bahia, Brasil
}

\section{Pedro Henrique Monteiro da Silva **} Universidade Federal do Sul da Bahia Itabuna, Bahia, Brasil

\section{Francismary Alves da Silva $* * *$} Universidade Federal do Sul da Bahia

Recebido em: 04 jan. 2021. Itabuna, Bahia, Brasil Aprovado em: 02 jun. 2021.

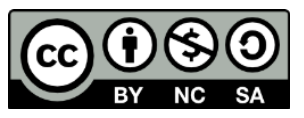

\footnotetext{
* Bacharel Interdisciplinar em Humanidades e graduando em História pela Universidade Federal do Sul da Bahia. Foi bolsista de iniciação científica no período de 2017-2020. Faz parte do Grupo de Pesquisas Avançadas em Materialidades, Ambiências e Tecnologias (UFSB) e integra o quadro de tesistas da Red Latinoamericana de Investigaciones en Prácticas y Medios de la Imagen. (saulo.carneiro@yahoo.com.br)

(i) https://orcid.org/0000-0003-4302-6019

(9) http://lattes.cnpq.br/3758277497764437

** Especialista em Direitos Humanos e Contemporaneidade (UFBA), Pós-Graduando em Direito Previdenciário, Bacharel em Humanidades (UFSB) e Graduando em Direito (UFSB). Membro do Grupo de Pesquisa e Extensão Pluralismo Jurídico e Usos Emancipatórios do Direito - UFSB/CNPq. Bolsista de Iniciação Científica Fapesb (2018-2020). Atualmente Bolsista de Iniciação Científica. Integrante do Programa Permanente de Extensão em Direitos Humanos da UFSB e do Grupo de Pesquisa e Extensão Pensamento Negro Contemporâneo - UFSB/CNPq. (phipiau@hotmail.com)

(D) https://orcid.org/0000-0001-9378-5756

(9) http://lattes.cnpq.br/8646541976160630

*** Professora Adjunta da Universidade Federal do Sul da Bahia (UFSB), onde atua no Centro de Formação em Políticas Públicas e Tecnologias Sociais - CFPPTS do Campus Jorge Amado (Itabuna - BA) e no Centro de Formação em Ciências Humanas e Sociais - CFCHS do Campus Sosigenes Costa (Porto Seguro - BA). Professora/orientadora do Programa de Pós-Graduação em Ensino e Relações Étnico-Raciais da UFSB Doutora, Mestra e Licenciada Plena em História pela Universidade Federal de Minas Gerais (UFMG). Pesquisadora dos seguintes Grupos de Pesquisa cadastrados no CNPq: Scientia \& Technica (UFMG), Núcleo de estudos afro brasileiros - NEAB (UFSB) e Grupo de Pesquisas Avançadas em Materialidades, Ambiências e Tecnologias (UFSB). (fran.ufsb@gmail.com)

(D) https://orcid.org/0000-0002-1583-5903

(9) http://lattes.cnpq.br/1454456137271310
} 


\title{
Resumo
}

O presente artigo se propõe analisar as inter-relações históricas entre a produção do discurso médico-científico, a maconha, seus usos e usuários, e o racismo científico durante a primeira metade do século $X X$, com um enfoque especial dirigido a atuação do médico e político José Rodrigues da Costa Dória, a partir do qual se investiga, ainda, o surgimento do "problema" da maconha por meio do referido discurso científico legitimador. A partir de revisão da bibliografia sobre o tema, e com suporte teórico da história das ciências, entre outras chaves de leitura, o presente artigo discute a influência do pensamento de Rodrigues Dória na formação das gerações seguintes de médicos, as afinidades de seu pensamento com a eugenia e, por fim, a emergência da ideologia proibicionista na formação social brasileira no pós-abolição, responsável por classificar as substâncias psicoativas enquanto drogas ou fármacos, institucionalizando o controle sobre os usuários.

Palavras-chave: Maconha. Discurso médico-científico. Ideologia proibicionista. José Rodrigues da Costa Dória. Racismo Científico.

\begin{abstract}
This article aims to analyze the historical inter-relationships between the production of medicalscientific discourse, marijuana, its uses and users, and scientific racism during the first half of the XX century, with a special focus on the work of the doctor and politician José Rodrigues da Costa Dória, from which the emergence of the "problem" of marijuana through the aforementioned legitimating scientific discourse is also investigated. Based on a review of the bibliography on the subject, and with theoretical support from the history of science, among other reading keys, this article discusses the influence of Rodrigues Dória's thought on the formation of the following generations of doctors, the affinities of his thought with eugenics, and, finally, the emergence of prohibitionist ideology in the post-abolition Brazilian social formation, responsible for classifying psychoactive substances as drugs or pharmaceuticals, institutionalizing control over users.
\end{abstract}

Keywords: Marijuana. Medical-scientific discourse. Prohibitionist ideology. José Rodrigues da Costa Dória. Scientific racism. 


\section{Introdução}

A cannabis spp, ${ }^{1}$ conhecida popularmente como maconha é atualmente uma das substâncias psicoativas mais consumidas no Brasil. ${ }^{2}$ Assim como sua popularidade não é recente, sua existência na forma em que a conhecemos hoje não é obra do acaso. Esse vegetal passou por diversos processos de melhoramento genético e pode ser considerado como um dos vegetais que o ser humano mais se empenhou em aprimorar para os seus variados usos, do industrial ao medicinal. Retratada até pelo grego Heródoto, ${ }^{3}$ é possível considerar a cannabis spp como uma das plantas mais antigas que o ser humano domesticou, aprimorou, e utiliza, de modo semelhante ao que ocorreu com o milho e a batata, a maconha é também resultado dessa intervenção humana.

Por não ser um vegetal nativo, a autoria de sua introdução na América Portuguesa é desconhecida e alvo de divergências. A quem atribua aos africanos escravizados a autoria da sua introdução, ${ }^{4}$ e que parece ter se tornado a tese mais aceita pelo discurso médico-científico. Contudo, há também quem aponte para o fato dos europeus terem tido contato com a cannabis spp antes da invasão da América, ${ }^{5}$ como iremos explorar neste trabalho mais a frente. Entretanto, essa querela não é o centro do nosso debate, apesar de ser necessário considerar todos os aspectos históricos que tais fatos carregam.

Considerando a riqueza histórica que a cannabis spp oferece como objeto de pesquisa, pretendemos estudá-la com um enfoque e amparo da história das ciências, tendo um recorte temático voltado para o advento da produção do discurso médico-científico sobre a planta no

\footnotetext{
${ }^{1}$ A cannabis spp é uma planta da família cannabaceae, variando entre três subespécies mais conhecidas, Indica, Sativa e ruderalis. Para mais detalhes ver: SANTOS, Rafael Guimarães dos. Breve panorama etnobotânico sobre a maconha. In: MACRAE, Edward; ALVES, Wagner Coutinho (org.). Fumo de Angola: canabis, racismo, resistência cultural e espiritualidade. Salvador: EDUFBA, 2016, 61-65; FARAG, Sayed; KAYSER, Oliver. The Cannabis Planta: Botanical Aspects. In: PREEDY, Victor (ed.). Handbook of Cannabis and Related Pathologies: Biology, Pharmacology, Diagnosis, and Treatment. London: 2017, 3-12; DUVALL, Chris S. The African roots of marijuana. Durham: Duke University Press, 2019, 35-39.

2 BASTOS, Francisco Inácio Pinkusfeld Monteiro et al. (Org.). III Levantamento Nacional sobre o uso de drogas pela população brasileira. Rio de Janeiro: FIOCRUZ/ICICT, 2017, p. 111.

3 ESCOHOTADO, Antonio. Historia general de las drogas. Madrid: Alianza Editorial, 1998, p. 76.

${ }^{4}$ PEREIRA, A. de P Leonardo. O cânhamo ou diamba e seu poder intoxicante. In: BRASIL. MINISTÉRIO DA SAÚDE. Maconha: coletânea de trabalhos brasileiros. Rio de Janeiro: Oficinas Gráficas do IBGE, 1958, p. 46.
}

${ }^{5}$ FRANÇA, Jean Marcel Carvalho. História da Maconha no Brasil. São Paulo: Três Estrelas, 2015, p. 26. 
Brasil no fim do século XIX e início do século XX. A escolha desse período para o recorte temporal ocorre, pois, foi principalmente durante a primeira metade do século XX que se deu o surgimento e difusão do discurso médico científico sobre a cannabis spp e, também, a internacionalização das proibições e criação de tratados internacionais, que resultaram em legislações proibitivas no Brasil e no qual foi desenvolvido todo o aparato legal da estrutura proibicionista moderna. ${ }^{6}$ Tendo em conta o recorte temporal, espacial e temático deste trabalho, ressalta-se a atuação profissional do médico e político sergipano José Rodrigues da Costa Dória (1857- 1938), considerado pioneiro nos estudos sobre efeitos sociais e patológicos dos usos da maconha no Brasil no início do século XX. ${ }^{7}$ Desse modo, o objeto deste trabalho se refere ao discurso médicocientífico sobre a maconha no século XX, contudo, buscamos compreender o advento do que convencionamos denominar de ideologia proibicionista - que teria se enunciado através do discurso médico-científico.

Entendemos por ideologia proibicionista um conjunto de ideias e representações predominantes no ideário de um grupo especializado, neste caso as ciências médicas, e consequentemente, na sociedade. ${ }^{8}$ Nesse sentido, a ideologia proibicionista se relacionava com um conjunto de valores e crenças da época em que se localizava, sendo enunciada a partir do discurso médico-científico que tratava do uso e controle de substâncias psicoativas buscando controlar as formas de alteração do estado natural da consciência, ${ }^{9}$ aqui trataremos especificamente das enunciações produzidas por esse discurso sobre a cannabis spp. Como veremos, as ideias de ideologia proibicionista, estilo e coletivo de pensamento ${ }^{10}$ serão mobilizadas na compreensão do lugar histórico, social, político e cultural dos agentes produtores de verdades científicas sobre a cannabis spp, a fim de compreender todas as camadas do discurso médico-científico que se referia a cannabis spp. Contudo, a ideologia proibicionista não se trata de uma categoria de análise, mas uma categoria classificatória e denominativa. Por meio da análise histórica da trajetória pessoal e profissional de Rodrigues Dória almejamos reconstituir parcialmente, reconhecendo as limitações impostas, como esse discurso médico-científico se deu, analisar seu advento, amadurecimento e, por fim, ascensão da ideologia proibicionista no interior no discurso médico-científico.

Para tanto, compreendemos ser fundamental, o amparo do arcabouço teórico da história das ciências e da saúde, de modo a buscar compreender como teria se dado a ascensão dessa

\footnotetext{
6 CARNEIRO, Henrique. Transformações do significado da palavra "droga": das especiarias coloniais ao proibicionismo contemporâneo. In: CARNEIRO, Henrique; VENÂNCIO, Renato Pinto (org.). Álcool e drogas na história do Brasil. São Paulo: Alameda, 2005. p. 18.

7 SAAD, Luísa Gonçalves. Fumo de negro: a criminalização da maconha no Brasil. 2013. Dissertação (Mestrado em História) - Faculdade de Filosofia e Ciências Humanas, Universidade Federal da Bahia, Salvador, p. 51.

8 ALTHUSSER, Louis. Ideologia e aparelhos ideológicos de Estado. Lisboa: Editorial Presença/Martins Fontes, 1980, p. 69.

9 ESCOHOTADO, Antonio. Historia general...Op cit., p.453.

10 FLECK, Ludwik. Gênese e desenvolvimento de um fato científico: introdução à doutrina do estilo de pensamento e do coletivo de pensamento. Belo Horizonte: Fabrefactum, 2010, p. 83
} 
corrente de forma concomitante, ou não, com a institucionalização das ciências médicas no Brasil, e as possíveis influências de correntes como o higienismo social, a eugenia e o racismo científico, ou não. Através do empreendimento desta análise, buscamos compreender como se constituiu a trajetória profissional de Rodrigues Dória, tendo em vista que sua formação e atuação estão localizadas em dois períodos distintos, o Império e a República, marcada por diferentes paradigmas de produção dos conhecimentos científicos. De um lado, por uma formação generalista dos literatos do século XIX, sucedida pela compartimentação e especialização do conhecimento científico no século XX. ${ }^{11}$ Diante desse contexto, urge a intenção de inquirir o lugar de enunciação discursivo de Rodrigues Dória, onde um sujeito que se constituiu em meio a esse rompimento se localizaria? Como isso teria afetado sua atuação profissional e leituras empreendidas sobre a realidade?

A partir dessa perspectiva, a intenção primária deste trabalho é compreender, através de levantamento e análise da historiografia sobre o tema, como se deram as relações entre a cannabis spp e o discurso médico-científico, tendo um enfoque direcionado para o surgimento da ideologia proibicionista no seio do próprio discurso médico-científico, discurso responsável, por sua vez, por fornecer evidências para a proibição e criminalização da planta, de seus usos e usuários. Partimos do pressuposto de que a cannabis spp foi transformada em um problema social no Brasil, e o proibicionismo local e global geraram diversas consequências sociais para o país, como a guerra às drogas, o encarceramento em massa, retroalimentados pelo racismo institucional e estrutural. Assim, consideramos relevante analisar a história da cannabis spp através da produção de verdade por parte do discurso médico-científico no início do século XX.

$\mathrm{Na}$ primeira parte deste trabalho buscamos analisar como se constituíram os sentidos sobre as relações raciais no Brasil pós-abolição, e como o racismo, intrínseco a história deste território denominado Brasil, foi fundante na constituição de diversos setores da vida, inclusive no discurso médico-científico. Por essa via, o racismo científico atravessa toda a nossa análise para compreender a maconha, seus usuários, as perspectivas médicas e contextos de suas proibições. Na segunda parte, a partir do pensamento da gênese e desenvolvimento de um fato científico de Ludwik Fleck, buscamos compreender e analisar os modos de produção do discurso médico-científico, tomando como evidência sua produção sobre a maconha. Consideramos que, em dado momento da história houve uma mudança de perspectiva sobre a cannabis spp, esta foi classificada e passou de um vegetal com utilizações medicinais para uma droga que precisava ter suas propriedades e seus usos investigados, e posteriormente controlados, tal papel foi desempenhado pelo discurso médico-científico, encarregado de produzir tais verdades. Nesse entremeio recorremos também ao conceito de ideologia de Louis Althusser a fim de compreender a formação e conformação da ideologia proibicionista no discurso médico-científico.

${ }^{11}$ SÁ, Dominichi Miranda de. A ciência como profissão: médicos, bacharéis e cientistas no Brasil (18951935). Rio de Janeiro: Fiocruz, 2006, p. 129. 


\section{Um ideário de nação no período pós-abolição: racismo, maconha e controle social}

O Brasil foi um dos últimos países a abolir a escravidão. Apenas em 1888 o sistema escravocrata foi extinto oficialmente e parte da população negra que ainda era escravizada foi considerada livre. Esse é um dos fatos históricos que evidenciam dimensões da estrutura econômica, sócio-cultural, política e militar de um sistema racialmente estratificado que se constituiu desde a invasão do continente americano pelos colonizadores portugueses. ${ }^{12}$ Durante a vigência do regime escravocrata no Brasil Colônia, a utilização da maconha foi vista de formas distintas. Se por um lado havia certa leniência dos senhores de engenho com relação ao seu uso, ${ }^{13}$ havia, além disso, uma perspectiva que parecia estar relacionada às condições de trabalho e produtividade das pessoas escravizadas que utilizavam a maconha. Para estes que se opunham ao uso, os efeitos provocados pela utilização da planta tornavam os negros mais preguiçosos, o que culminaria na redução de sua produtividade. Para além disto, era um hábito de origem africana, que deveria ser combatido de modo a evitar que o mesmo permeasse na cultura local. ${ }^{14}$ Com isso, demonstra-se que ainda no período escravocrata a preocupação com relação ao uso da maconha já vinha tomando forma com outro caráter.

A abolição da escravatura e a proclamação da República marcaram uma mudança de paradigma com relação à percepção sobre os usos da maconha, essa mudança ocorre, em partes, devido ao ingresso de médicos na administração pública e seu crescente acúmulo de poder. ${ }^{15}$ Tendo em vista que, à época do pós-abolição os negros compunham numericamente a maioria da população, era latente por parte das classes dominantes o medo de dominação cultural e revoltas por parte destes grupos étnicos subalternizados, ${ }^{16}$ a exemplo do que ocorreu na Revolução Haitiana. ${ }^{17}$ Além do que, a constituição da República necessitava de valores, ideais de civilidade e pacificação, que tinham como fim consolidar uma identidade nacional e, nesse sentido, os elementos culturais não eurocêntricos, como aqueles mantidos pelos povos africanos e seus descendentes, eram um empecilho aos anseios e objetivos da nova República. ${ }^{18}$ Para garantir o sucesso do projeto de uma nação pautada em valores cristãos e tendo como base

\footnotetext{
12 NASCIMENTO, Abdias do. O quilombismo: documentos de uma militância pan-africanista. Rio de Janeiro: Fundação Cultural Palmares, 2002, p. 23.

13 FREYRE, Gilberto. Nordeste: aspectos da influência da cana sobre a vida e a paisagem do nordeste do Brasil. São Paulo: Global, 2013, p. 36.

14 FRANÇA, Jean Marcel Carvalho. História da Maconha... Op. cit., p.36.

15 CHALHOUB, Sidney. Cidade Febril: cortiços e epidemias na Corte imperial. Rio de Janeiro: Companhia das Letras, 2017, p. 41.

${ }^{16}$ AZEVEDO, Célia Maria Marinho de. Onda negra, medo branco: o negro no imaginário das elites - Século XIX. Rio de Janeiro: Paz e Terra, 1987.

17 Para mais detalhes sobre o assunto ver BUCK-MORSS, Susan. Hegel e Haiti. Novos Estudos - Cebrap. São Paulo, n. 90, p. 131-171, 2011, p. 131-171. Disponível em: https://doi.org/10.1590/S010133002011000200010. Acesso em: 26 dez. 2020.
}

18 SAAD, Luísa Gonçalves. Fumo de negro...Op.cit., p.123. 
cultural uma matriz eurocêntrica, os diversos elementos culturais dos povos negros foram perseguidos, criminalizados e embranquecidos e, em meio a essa investida estavam ainda as religiões de matriz africana, o samba e a capoeira. ${ }^{19}$

A relação das autoridades com a maconha no período anterior à abolição da escravatura e no pós-abolição é ambígua. Os sentidos atribuídos à planta parecem variar conforme a origem dos usuários e os objetivos de seu uso, aparentemente parecem tratar-se de duas plantas diferentes. Apesar da recriminação do uso por parte do povo negro, no período que antecedeu a abolição, a maconha era utilizada como planta medicinal, e teve sua primeira menção no livro de botânica Flora Brasiliensis (1853) de Carl Friedrich Ph. Von Martius, em que é descrita como calmante, desintoxicante e antiespasmódica, a planta ainda era vendida em farmácias e boticários como remédio. ${ }^{20}$ Isso revela uma percepção ambígua com relação à maconha no período. Nas farmácias e boticários, espaços destinados a pessoas mais abastadas, que em sua quase totalidade eram brancas, era vendida como remédio para os extratos sociais que não eram lidos como marginais por sua identidade étnico-racial.

O entendimento do potencial medicinal da maconha, mesmo que ambíguo, começa a mudar com a publicação de uma das mais famosas obras sobre medicina popular da época, o Formulário e Guia Médico (1908) de Pedro Luiz Napoleão Chernoviz. O autor descreve os efeitos do uso da maconha e alguns modos de preparo do haxixe. ${ }^{21}$ Ele acreditava que a planta e o hábito de utilizá-la, devido a sua origem africana - fato que não pôde ser confirmado pela historiografia que aborda o tema - seria um mal imputado aos brasileiros pela raça negra. ${ }^{22}$ As mudanças do entendimento sobre o uso medicinal da maconha, coincidentemente, começam a ocorrer no período do pós-abolição. Os usos e efeitos da maconha passaram a ser cada vez mais interpretados a partir do que se sabia sobre o ópio ${ }^{23}$ e, poucos anos depois, os esboços da ideologia proibicionista começaram a se materializar no discurso médico-científico.

É provável que a criminalização dos usos da maconha no Brasil tenha ligação com a abolição da escravidão no país. Apesar da primeira norma jurídica que proibiu o uso e venda de maconha ser datada de 4 de outubro de 1830 não ter caráter nacional e limitar-se a cidade do Rio de Janeiro, ${ }^{24}$ após a abolição da escravidão, em 1888, é que o discurso médico-científico começa a esboçar e enunciar o que viria a ser a ideologia proibicionista, e, consequentemente ganha espaço e adeptos na cena pública. No imaginário da época, era necessário criar

19 LUNARDON, Jonas Araujo. Maconha, Capoeira e Samba: a construção do proibicionismo como uma política de criminalização social. Anais do I Seminário Internacional de Ciência Política da Universidade Federal do Rio Grande do Sul, Porto Alegre, 2015, p. 7.

20 FRANÇA, Jean Marcel Carvalho. Op. cit., p.17.

${ }^{21}$ Resina extraída das flores da cannabis $s p$, e que possui alta concentração de Tetrahidrocanabinol (THC). 22 FRANÇA, Jean Marcel Carvalho. Op. cit., p.18.

${ }^{23}$ SOUZA, Jorge Emanuel Luz de. Sonhos da diamba, controles do cotidiano: uma história da criminalização da maconha no Brasil republicano. Salvador: EDUFBA, 2015. p. 127.

24 BARROS, André; PERES, Marta. Proibição da maconha no Brasil e suas raízes históricas escravocratas. Periferia, Rio de Janeiro, v. 3, n. 2, p. 1-20, 26 dez. 2011, p. 7. 
mecanismos institucionais para exercer controle social sob a população negra, vista como uma ameaça à ordem social almejada e ao ideário de "nação" que se pretendia efetivar. ${ }^{25}$ Tal pensamento encontra ressonância em Casa Grande e Senzala, por exemplo, obra de 1933 em que Gilberto Freyre desenvolve a ideia de democracia racial, que aponta para uma pretensa passividade dos escravizados e a união pacífica das diferentes raças. ${ }^{26}$

A discussão em torno da origem e responsabilidade da introdução da cannabis no Brasil é fundamental para compreender o imaginário que seria constituído sobre a planta décadas após a sua introdução e disseminação no território. Alguns historiadores apontam que a planta teria sido introduzida no Brasil por negros escravizados, outros contestam tal afirmação. Há, contudo, uma perspectiva que parece considerar evidências de ambos os lados, sem deixar de apontar para as chaves de leitura utilizadas pelos que tentaram elucubrar sobre a questão da origem da planta. Jorge Emanuel Luz de Souza indica que autores como José Rodrigues da Costa Dória e tantos outros proibicionistas não estavam errados ao afirmarem que haveriam ligações entre a origem e difusão da maconha no Brasil, o continente e cultura africana, porém, estes utilizavam de ideologias racistas, higienistas e eugenistas para atribuir culpa aos negros por um problema criado pela branquitude e retroalimentado pela ideologia proibicionista que compôs o pensamento científico do século XX. ${ }^{27}$

Rodrigues Dória, que é considerado por alguns autores como o pioneiro no desenvolvimento da corrente científica do proibicionismo da maconha no Brasil, estudou na Faculdade de Medicina da Bahia, onde retornou para ser professor. Lá também foi aluno de Nina Rodrigues, ${ }^{28}$ um dos principais nomes do higienismo social e da eugenia no Brasil. É interessante notar como estão imbricados na figura de Nina Rodrigues tanto o discurso médico quanto jurídico. Ambos dividiam o interesse e atuavam na área da Medicina Legal, além disso, o discurso político, que era disseminado como discurso nacional por Rodrigues Dória assemelhava-se a ideia de higienismo social defendida por Nina Rodrigues, que desenvolveu todo seu pensamento articulando raça e criminalidade. ${ }^{29}$ Dória via a maconha como um mal africano que deveria ser combatido, pois, seria um hábito de seres naturalmente inferiores com ligações estreitas com a criminalidade e, de modo algum, poderia afetar a formação da nova nação.

A ideologia proibicionista surge e toma força no início do século $\mathrm{XX}$, concomitantemente, a medicalização da sociedade e ascensão da instituição médica, que passou a ocupar cada vez mais um espaço e poder discursivo, não apenas na sociedade, bem como nas estruturas do

\footnotetext{
25 SOUZA, Jorge Emanuel Luz de. Sonhos da diamba... Op. cit., p.42.

26 FREYRE, Gilberto. Casa-grande \& senzala: formação da família brasileira sob o regime da economia patriarcal. São Paulo: Global, 2003, p. 322.

27 SOUZA, Jorge Emanuel Luz de. Op. cit., p.182.

28 Idem, p. 36.

${ }^{29}$ RODRIGUES, Marcela Franzen. Raça e criminalidade na obra de Nina Rodrigues: uma história psicossocial dos estudos raciais no Brasil do final do século XIX. Estudos e Pesquisas em Psicologia, Rio de Janeiro, v. 15, n. 3, p. 1121. Disponível em: http://pepsic.bvsalud.org/scielo.php?script=sci_arttext\&pid=S180842812015000300019\&lng=pt\&nrm=iso. Acesso em: 26 dez. 2020.
} 
Estado. José Rodrigues da Costa Dória teria sido o primeiro a lançar a pedra fundamental do proibicionismo brasileiro da maconha. A influência e inclusive reprodução da teoria lombrosiana 30 e do surgimento e popularização das correntes eugenistas no Brasil, principalmente nas escolas de Medicina, um de seus principais redutos, ${ }^{31}$ marcaram esse momento. Tal acontecimento ocorre como desdobramento de campanhas pautadas por médicos, que tinham como objetivos descredibilizar cada vez mais a medicina popular, em especial a que era praticada pelos povos originários, africanos e descendentes, o que favorecia a constituição e consolidação da instituição médica como autoridade científica, política e branca. A publicação de um relatório científico em 1916 por Arthur Neiva e Belisário Pena e a posterior fundação da Liga Pró-Saneamento do Brasil marcaram o início da constituição do movimento sanitarista no país ${ }^{32}$ e a consolidação da instituição médica, que passou a ocupar cada vez mais um papel central na formação social brasileira e na construção do almejado ideário nacionalista.

Assim, fica evidente a preocupação do grupo racial dominante com a manutenção das estruturas de exploração e dominação das elites nacionais que definiam o status quo vigente, bem como o embranquecimento forçado do negro como única forma de melhoria sócioeconômica, ${ }^{33}$ produzindo o discurso médico-científico para justificar uma lógica de inferiorização racial que encontrou amparo na produção de leis. ${ }^{34}$ É no racismo institucional que se manifestam dispositivos jurídicos para o controle e inferiorização de grupos subalternizados, posto que é pelas instituições oficiais, inclusive científicas, pela figura do Estado e pelo sistema de justiça que a ficção racial de hierarquias sociais se naturaliza diante de estruturas socioeconômicas de exploração e dominação dos corpos negros. ${ }^{35}$ Portanto, o discurso médico-científico foi responsável por fornecer evidências para implementação de políticas públicas e criação de leis que eram fundamentadas pelo racismo estrutural intrínseco à história do Brasil, do processo de escravização à abolição, sendo este um pressuposto central e fundamental no proibicionismo brasileiro, como veremos a seguir.

\footnotetext{
${ }^{30}$ Cesare Lombroso foi um médico e professor considerado precursor na patologização de criminosos, serviu de referência para Rodrigues Dória e Nina Rodrigues, influenciou os respectivos autores sobre a associação entre raça e criminalidade. Para mais informações ver RODRIGUES (2015) e SAAD (2013).

31 SOUZA, Vanderlei Sebastião de. A eugenia brasileira e suas conexões internacionais: uma análise a partir das controvérsias entre Renato Kehl e Edgard Roquette-Pinto, 1920-1930. História, Ciências, Saúde Manguinhos. Rio de Janeiro, v. 23, p. 95.

32 CASTRO-SANTOS, Luiz Antonio de; FIGUEIREDO, Regina Érika Domingos de. Belisário Penna, combatente: um capítulo da história da saúde pública brasileira. Saúde e Sociedade, São Paulo, v. 21, n. 4, p. 848-857, 2012, p. 850. Disponível em: https://doi.org/10.1590/S0104-12902012000400005. Acesso em: 26 dez. 2020.

33 NASCIMENTO, Abdias do. O quilombismo... Op. cit., p.28-29.

34 SANTOS, Gislene Aparecida dos. A invenção do "ser negro": um percurso das ideias que naturalizaram a inferioridade dos negros. São Paulo: Pallas, 2002. p. 160.
}

35 ALMEIDA, Sílvio Luiz de. Racismo estrutural. São Paulo: Pólen Produção Editorial LTDA, 2018, p. 22-27. 


\section{Coletivo de pensamento, raça e saúde: interfaces entre o discurso médico- científico e o proibicionismo}

A cannabis spp nem sempre foi considerada nociva pelo discurso médico-científico. A planta foi utilizada pela medicina desde períodos remotos, figurando na primeira farmacopeia de que se tem registro, há 4.000 anos. ${ }^{36}$ Ela também pode ser considerada uma das plantas psicoativas mais antigas que se tem registro de uso. Artefatos históricos atestam que há 2.400 anos já se consumia a planta para alterar a consciência. ${ }^{37}$ Esses usos continuaram a existir até as primeiras proibições e restrições aos usos medicinais e recreativos da planta. De grande aliada da Medicina, a cannabis spp passou à inimiga a ser combatida.

Conjecturamos sobre a possibilidade de início do que se convencionou chamar de ideologia proibicionista, tratando dos usos da maconha no Brasil, a partir da produção do médico, professor e figura política José Rodrigues da Costa Dória. Em 1915, Rodrigues Dória - como era mais conhecido, apresentou seu artigo intitulado "Os fumadores de maconha: efeitos e males do vício" durante o Segundo Congresso Científico Pan-Americano, realizado em Washington. ${ }^{38} \mathrm{O}$ texto foi republicado diversas outras vezes e inspirou gerações de médicos proibicionistas que viam no autor uma grande referência no combate ao uso da maconha, sendo considerado uma autoridade moral. ${ }^{39}$ Ao retratar as obras científicas que se tornam referências para determinadas áreas do conhecimento, Ludwik Fleck classifica estas obras como "instituições" desses coletivos, e que mereceriam atenção particular na análise do pensamento. O texto de Rodrigues Dória pode ser considerado, utilizando da metáfora de Fleck, uma espécie de "catecismo do proibicionismo brasileiro". 40 Nele, assim como em outros textos e documentos produzidos pela elite branca intelectualizada no período, a abolição da escravidão no Brasil é descrita como uma festa que promoveu a integração do povo negro à sociedade. Reforça-se a ideia de uma suposta democracia racial em que os povos antes escravizados passaram a viver em condições de igualdade com os brancos, como se isso tivesse ocorrido de forma benevolente e instantânea. Contudo, Rodrigues Dória afirmava que a cannabis spp seria um castigo da raça subjugada como vingança contra quem os escravizou.

Dentre esses males que acompanharam a raça subjugada, e como um castigo pela usurpação do que de mais precioso tem o homem - a sua liberdade -, ficounos o vício pernicioso e degenerativo de fumar as sumidades floridas da planta

36 GONTIÈS, Bernard; ARAÚJO, Ludgleydson Fernandes de. Maconha: uma perspectiva histórica, farmacológica e antropológica. Mneme: revista de humanidades, Caicó, v. 4, n. 7, p. 47-3, 2003, p. 51. Disponível em: https://www.periodicos.ufrn.br/mneme/article/view/164. Acesso em: 26 dez. 2020.

37 REN, Meng et al. The origins of cannabis smoking: Chemical residue evidence from the first millennium BCE in the Pamirs. Science Advances, Washington, v. 5, n. 6, p. 1-8, 2019, p. 3. Disponível em: https://advances.sciencemag.org/content/5/6/eaaw1391. Acesso em: 26 dez. 2020.

38 DÓRIA, José Rodrigues da Costa. Os fumadores de maconha: efeitos e males do vício. In: HENMAN, Anthony; PESSOA JUNIOR, Osvaldo (org.). Diamba Sarabamba: (coletânea de textos brasileiros sobre a maconha). São Paulo: Ground, 1986. p. 19-38.

39 SAAD, Luísa Gonçalves. Fumo de negro... Op. cit., p.11.

40 FLECK, Ludwik. Gênese e desenvolvimento... Op. cit., p.27. 
aqui denominada fumo de Angola, maconha e diamba, e ainda, por corrupção, liamba ou riamba. ${ }^{41}$

Tal concepção revela que, se por um lado Rodrigues Dória acreditava que a abolição teria promovido a incorporação do povo negro à condição de cidadão, por outro lado, seus costumes e cultura, sobretudo os usos da cannabis spp, representariam uma chaga indesejável e prejudicial para as aspirações de constituição da nação, que não poderia ter no seu bojo elementos culturais africanos tidos como inferiores, degenerados. Como mencionamos anteriormente, a afirmação da origem africana da planta foi sustentada de forma recorrente por Rodrigues Dória, assim como os que o sucederam, a exemplo de Francisco de Assis Iglésias, Garcia Moreno, Adauto Botelho e Pedro Pernambuco. ${ }^{42}$ Entretanto, evidências históricas mostram a presença da maconha na Europa anos antes da invasão da América. ${ }^{43}$ Essa hipótese, amplamente aceita pela historiografia sobre o tema, evidencia que a necessidade de apontar a África como lugar de origem da cannabis spp estava mais relacionada com a intenção de atribuir culpa pela introdução da planta no Brasil do que, de fato, com o intento de registrar sua origem.

Diante desse contexto, é possível afirmar que o coletivo de pensamento ${ }^{44}$ eugenista brasileiro, e aqui destaca-se a figura de Nina Rodrigues, que buscava encontrar interpretações antropológicas e psicológicas associadas à raça negra no cometimento de crimes, em grande parte, forneceu elementos teóricos para o pleno desenvolvimento do estilo de pensamento 45 proibicionista em questão. Assim, a ideologia proibicionista brasileira partilhou de conceitos e ideias do movimento eugenista brasileiro, tendo conexões e afinidades com essa corrente, pois, para os proibicionistas era primordial criar justificativas, teorias e leis, de modo a racionalizar a subalternização de um grupo em detrimento de outro. Portanto, antes de ser uma questão de saúde pública, como defendia Rodrigues Dória e seus seguidores, estes travavam uma verdadeira guerra cultural, instrumentalizando os aparatos da estrutura social pelo racismo científico que também configurará o eugenismo brasileiro ${ }^{46}$ e que, por sua vez, possibilitará a atualização de um fenômeno complexo e vigente até a atualidade, o racismo estrutural.

\footnotetext{
41 DÓRIA, José Rodrigues da Costa. Os fumadores de maconha... Op. cit., p.21.

42 Os seguintes autores afirmam a origem africana da cannabis sp: INGLÉSIAS, Francisco de Assis. Sobre o vício da diamba. In: HENMAN, Anthony; PESSOA JUNIOR, Osvaldo (org.). Diamba Sarabamba: (coletânea de textos brasileiros sobre a maconha). São Paulo: Ground, 1986. p. 39-52; MORENO, Garcia. Aspectos do maconhismo em Sergipe. In: HENMAN, Anthony; PESSOA JUNIOR, Osvaldo (org.). Diamba Sarabamba: (coletânea de textos brasileiros sobre a maconha). São Paulo: Ground, 1986. p. 53-66.; BOTELHO, Adauto; PERNAMBUCO, Pedro. Vício da diamba. In: MINISTÉRIO DA SAÚDE. Maconha: coletânea de trabalhos brasileiros. Rio de Janeiro: Oficinas Gráficas do IBGE, 1958. p. 28-31.
}

43 Pelo menos três referências utilizam tal argumento, a saber: ESCOHOTADO, Antonio. Historia general de las drogas. Madrid: Alianza Editorial, 1998, p. 47; FRANÇA, Jean Marcel Carvalho. História da Maconha no Brasil. São Paulo: Três Estrelas, 2015, p. 26; MOTT, Luiz. A maconha na história do Brasil. In: HENMAN, Anthony; PESSOA JUNIOR, Osvaldo (org.). Diamba Sarabamba: (coletânea de textos brasileiros sobre a maconha). São Paulo: Ground, 1986. p. 132.

44 FLECK, Ludwik. Op. cit., p.82.

${ }^{45}$ Idem.

46 SOUZA, Vanderlei Sebastião de. A eugenia brasileira e suas conexões internacionais: uma análise a partir das controvérsias entre Renato Kehl e Edgard Roquette-Pinto, 1920-1930. História, Ciências, Saúde Manguinhos. Rio de Janeiro, v. 23, supl., p.93-110, 2016, p. 96. 
Concomitantemente, já no início do século XX, mostrava-se urgente a necessidade, por parte não só do discurso médico-científico, bem como do pensamento hegemônico das elites brancas, de se criar um ideário de nação, promover uma cultura brasileira una à semelhança da elite branca, i.e., que não abarcasse os costumes e tradições do povo negro nem dos povos originários. Construir um conceito de nação "harmoniosa", "civilizada" e "pacífica" aos moldes almejados significava, na prática, silenciar culturas residentes que constituem o Brasil por meio do discurso científico e do discurso político, através das hierarquias de classe, de raça, de gênero, entre outras configurações que deveriam ser mobilizadas em prol da noção de nação e progresso. É nesse ínterim de construção de uma nação brasileira que se configura o ideário da miscigenação, ideário que encontra eco na obra de Gilberto Freyre ${ }^{47}$ e que teria forte potencial de apagamento dos conflitos raciais e sentimentos de reparação, além de ser uma estratégia bastante eficaz para a manutenção de estruturas socioeconômicas vigentes desde a colônia. Nesse mesmo contexto ainda poderíamos mencionar os conhecidos acontecimentos decorrentes da Reforma Pereira Passos no Rio de Janeiro, capital do jovem Estado republicano que passou por reestruturação urbana fruto de novos padrões de higiene, de organização urbanística e de progresso, mas, certamente, fruto de padrões orientados por determinada visão/ideário de nação, tal como aponta Sidney Chalhoub, ${ }^{48}$ por exemplo.

A instituição médica exerceu um papel fundamental na viabilização desse ideário de nação, foi responsável por disseminar ideais eugenistas e higienistas. O discurso médico forneceu as rubricas necessárias para implementação de políticas públicas eugenistas que viam na possibilidade de embranquecimento da população um vetor de progresso e avanço social. ${ }^{49}$ Nesse sentido, a cannabis mostrou-se como um enorme empecilho aos interesses de constituição da almejada nação e da instituição médica, que necessitava da distinção entre 'droga' e 'fármaco' para consolidar o monopólio do tratamento e da cura ${ }^{50}$ através da prescrição, tendo como contrapartida a validação recebida da sociedade. Ao mesmo tempo, a cannabis se mostrava a personificação do inimigo perfeito a ser combatido pelas elites constituintes da dita nação brasileira em construção: costume vinculado a antigos escravos, vício típico de negros que teriam trazido um mal africano para o solo brasileiro, portanto, elemento a ser diferenciado, discriminado, higienizado e eugenizado.

Não coincidentemente, a ideologia proibicionista brasileira surge entre dois movimentos historicamente relevantes para a instituição médica no Brasil. De um lado, a ideologia proibicionista surge e ganha força pouco tempo após a apresentação do artigo "Os fumadores de maconha: efeitos e males do vício" (1915) de Rodrigues Dória em Washington, momento de grande profusão dos ideais da corrente médica eugenista, ${ }^{51}$ que teve como um dos principais

\footnotetext{
47 FREYRE, Gilberto. Casa-grande \& senzala... Op. cit., p.116.

48 CHALHOUB, Sidney. Cidade Febril... Op.cit, p.67.

49 SOUZA, Vanderlei Sebastião de. A eugenia brasileira... Op. cit., p.105.

50 SAAD, Luísa Gonçalves. Op. cit., p.91.

51 SOUZA, Vanderlei Sebastião de. Op. cit., p.96.
} 
cânones o já mencionado médico Nina Rodrigues, sucedido por Rodrigues Dória na Faculdade de Medicina da Bahia, e representante de concepções eugenistas amplamente aceitas até a primeira metade do século XX. ${ }^{52} \mathrm{~A}$ ideologia proibicionista ganhou relevo concomitantemente à escola eugenista, em uma espécie de movimento de sucessão e simultaneidade de ideias. ${ }^{53}$ Paralelamente, sua ascensão ocorre, em um período próximo à criação do que hoje chamamos de Movimento Sanitarista Brasileiro, liderado por Belisário Penna e Arthur Neiva, entre 1918 e 1920, momento em que a medicina passou a ter cada vez mais importância e destaque na sociedade brasileira. ${ }^{54}$

É válido lembrar que, antes disso, o lugar ocupado pela medicina pertencia, em grande parte, ao campo da "medicina popular', isto é, um conjunto de saberes e práticas que geralmente eram realizadas e transmitidas por meio da oralidade e associadas a diferentes hábitos e costumes de etnias indígenas e culturas africanas, tendo na vegetação nativa seu principal recurso no tratamento de doenças. Porém, com o estabelecimento paulatino do saber médico especializado e pautado nos rigores científicos oriundos de uma instituição detentora do monopólio da cura e do tratamento de doenças, cada vez mais as práticas medicinais tradicionais e populares passaram a ser marginalizadas e criminalizadas, ${ }^{55}$ a exemplo do "curandeirismo", que passou a figurar como prática criminal no código penal de 1940.

A virada do século XIX para o XX marca uma profunda mudança no paradigma científico da época, mudança em grande parte estimulada pela efervescência que a produção científica passa a ocupar na cena pública durante o período em questão. ${ }^{56}$ Nesse ínterim, os ditos "literatos generalistas" que antes ocupavam majoritariamente o espaço de produção científica, vão paulatinamente perdendo espaço na cena pública devido à emergência de um novo paradigma: a especialização médica. Conforme aponta Dominichi Miranda de Sá ao descrever o período em questão na obra A ciência como profissão: médicos, bacharéis e cientistas no Brasil (1895-1935), generalistas dão lugar a especialistas e, com isso, pode-se dizer que o início do século XX foi marcado pelo deslocamento da medicina para o centro das ciências no Brasil. ${ }^{57}$ Esta, mesmo sendo um ramo da ciência, se desenvolveu de forma heterogênea, sob diferentes condições e pressupostos, sendo imposto a este ramo científico uma pressão externa por resultados. ${ }^{58}$

\footnotetext{
52 RODRIGUES, Marcela Franzen. Raça e criminalidade... Op. cit., p.1119. 2010, p. 13. em: 26 dez. 2020.

55 SAAD, Luísa Gonçalves. Op. cit., p.69.

56 SÁ, Dominichi Miranda de. A ciência como profissão... Op. cit., p.33.

57 Ibidem, p. 46.

58 FLECK, Ludwik. Op. cit., p.198.
}

53 SCHAFER, L; SCHNELLE, T. In: FLECK, Ludwik. Gênese e desenvolvimento de um fato científico: introdução à doutrina do estilo de pensamento e do coletivo de pensamento. Belo Horizonte: Fabrefactum,

54 CASTRO-SANTOS, Luiz Antonio de; FIgUEIREDO, Regina Érika Domingos de. Belisário Penna, combatente: um capítulo da história da saúde pública brasileira. Saúde e Sociedade, São Paulo, v. 21, n. 4, p. 848-857, 2012, p. 852. Disponível em: https://doi.org/10.1590/S0104-12902012000400005. Acesso 
A centralidade da instituição médica no rol das ciências e sobremaneira na sociedade, garantiu a ela presença contundente nas esferas de poder ou, como temos afirmado aqui, grande destaque na cena pública brasileira no período em questão e nas décadas seguintes, até a atualidade. Isso se comprova observando como, ao longo da história, ocorreu um estabelecimento cada vez mais gradual de médicos de formação nas esferas de poder. Um exemplo bastante propício para nossa contextualização temática seria a criação da Comissão Nacional de Fiscalização de Entorpecentes em 1936, um órgão de Estado, composto majoritariamente por médicos, ${ }^{59}$ que desenvolveu políticas públicas de combate às drogas por meio da patologização, criminalização e repressão dos usuários, concepção que, sabemos, pelos imaginários, e, por métodos e práticas concretas, se mantém até a atualidade na nossa formação social.

É nesse amplo contexto de sucessão e simultaneidade de ideias ${ }^{60}$ eugenistas, sanitaristas e proibicionistas, contexto também marcado pela valorização e especialização do saber médicocientífico na cena pública, que as primeiras hipóteses sobre as consequências do uso da maconha levantadas por Rodrigues Dória serão desenvolvidas e amplamente disseminadas. Vale destacar, desde já, que mesmo à época, as hipóteses de Rodrigues Dória mostravam-se frágeis do ponto de vista científico, contudo, certamente sólidas diante do quadro ideológico do contexto pósabolição. Tais hipóteses estavam atreladas a pontos de vistas específicos do período posterior à abolição, assim, é possível dizer que ocorreu um processo de sucessão e simultaneidade ${ }^{61}$ desses pontos de vista após a publicação do artigo de Rodrigues Dória. O ponto de vista impresso pela instituição médica era, e ainda é, condicionado pela cultura e história através do conjunto de valores e símbolos de uma sociedade, neste aspecto estão inclusos tanto as correntes médicocientíficas que antecedem a corrente proibicionista, como as que ocorreram concomitantemente e as que o sucederam. ${ }^{62} \mathrm{Em}$ outras palavras, é possível observar, na atualidade e no período imediato do pós-abolição, uma amálgama entre concepções históricas, culturais, socioeconômicas e a produção científica decorrente e, ao mesmo tempo, fundadora.

Dessa forma, é a partir da corrente proibicionista que se forma no Brasil uma sólida ideologia, amparada em contexto histórico, nacionalista, racial, científico e político, de combate à cannabis. Esse conjunto de ideias não tinha como objetivo promover o avanço do conhecimento científico e ter como resultado o progresso social, mas sim, oferecer subsídios para implementação de políticas de controle social sobre o povo negro. ${ }^{63}$ A cannabis torna-se mais um elemento cultural para se promover a criminalização de todo um grupo, ao descrever o ritual de uso em um 'Clube de Diambistas' no Maranhão, Iglésias busca compreender o significado de

\footnotetext{
59 BRASIL. MINISTÉRIO DA SAÚDE. Maconha: coletânea de trabalhos brasileiros. Rio de Janeiro: Oficinas Gráficas do IBGE, 1958, p. 105.

60 SCHAFER, L; SCHNELLE, T. In: FLECK, Ludwik. Op. cit., p. 13.

${ }^{61}$ FLECK, Ludwik. Ibidem, p. 125.

62 Idem.

63 SOUZA, Jorge Emanuel Luz de. Op. cit., p.63.
} 
termos, segundo ele africanos e concluí que: "É interessante notar como, apesar de tantos anos que nos separam da escravatura, ainda acompanham o vício da diamba termos vindos com ela das costas africanas.", ${ }^{64}$ desse modo, Iglésias busca identificar elementos culturais africanos no ritual do 'Clube de Diambistas', assim como no movimento eugenista e no sanitarista, o enfoque dado pelo autor parece apontar para a intenção de caracterizar esse uso ritualístico como um costume africano, que não caberia no bojo da nação de matriz eurocêntrica que se almejava forjar.

Assim, de certa forma, a constituição da ideologia de combate à maconha tem seu início com Rodrigues Dória, num contexto de efervescência de novas ideias e conhecimentos científicos, de novas práticas legitimadas e ditas civilizadas. Até os dias atuais, essa ideologia proibicionista, e tudo que ela carrega consigo e representa, ainda é latente na sociedade brasileira, tendo mudado de forma e se transformado ao longo do tempo, mas mantendo sua essência proibicionista, excludente, elitista e racista.

Por meio da interrelação entre os conceitos de ideologia de combate à maconha65 e da incorporação da classificação do proibicionismo enquanto um paradigma é possível observar um intento central em tornar ilegal todas as substâncias entorpecentes a partir do ano de $1900 .{ }^{66}$ Dito de outra forma, o movimento proibicionista atua de modo a garantir o monopólio de controle e produção de verdade sobre as substâncias psicoativas, tendo sido responsável por classificar e separar drogas legais de ilegais. ${ }^{67}$ Esse paradigma é posto em funcionamento a partir das primeiras convenções e conferências internacionais sobre drogas, nesses espaços os estadunidenses assumiram a liderança no combate às drogas. ${ }^{68}$ Assim, é possível inferir que o fenômeno do surgimento e ascensão do proibicionismo não se deve exclusivamente a uma causa ou fator, portanto, não é possível atribuir somente às disputas e controles geopolíticos como responsáveis pela origem do paradigma proibicionista.

Destacar a relevância das relações internacionais nas proibições locais e internacionais da cannabis spp é fundamental. Em 1924 a cannabis spp foi incluída nas discussões durante a II Conferência Internacional do Ópio, realizada em Genebra, que teve como resultado a recomendação de sua proibição. Há, contudo, uma querela sobre a atuação dos delegados brasileiros na inclusão da maconha nas discussões e sua importância na proibição internacional

64 INGLÉSIAS, Francisco de Assis. Sobre o vício da diamba. In: HENMAN, Anthony; PESSOA JUNIOR, Osvaldo (org.). Op. cit., p. 46.

${ }^{65}$ SAAD, Luísa Gonçalves. Op. cit., p. 127.

66 ESCOHOTADO, Antonio. Op.cit., p.453.

67 CARNEIRO, Henrique. As necessidades humanas e o proibicionismo das drogas no século XX. Outubro, São Paulo, v. 6, p. 115-128, 2002, p. 116. Disponível em: http://outubrorevista.com.br/as-necessidadeshumanas-e-o-proibicionismo-das-drogas-no-seculo-xx/. Acesso em: 26 dez. 2020.

68 FIORE, Maurício. O lugar do Estado na questão das drogas: o paradigma proibicionista e as alternativas. Novos Estudos - CEBRAP, São Paulo, n. 92, p. 9-21, 2012, p. 9. Disponível em: http://dx.doi.org/10.1590/S0101-33002012000100002. Acesso em: 26 dez. 2020. 
da cannabis spp. ${ }^{69}$ Porém, José Lucena, em um texto sobre os usuários de maconha em Pernambuco, afirma que os delegados brasileiros, Pedro Pernambuco Filho e Humberto Gotuzzo, teriam sido os responsáveis pela proibição da venda da maconha. ${ }^{70}$ Assim, o que parece ocorrer é que não havia um alinhamento automático do Brasil as tendências internacionais de proibição da cannabis spp somente devido à influência de outros países, mas sim tendências endógenas que encontraram condições propicias para se desenvolverem. Nesse sentido, é importante ressaltar o papel das discussões internas, que resultaram na proibição da cannabis spp no Brasil em 1932, e em 1937 nos Estados Unidos. ${ }^{71}$

É importante reconhecer as conjunções de fatores que em determinados momentos históricos se inter-relacionaram e forneceram as condições materiais para a construção de uma visão de mundo. Compreendendo tais pressupostos, optamos por um desdobramento das categorias analíticas anteriormente dispostas e convencionamos, a partir do entendimento da ideologia enquanto uma imagem da realidade, que pode não corresponder à realidade, podendo ser influenciada pelas concepções de mundo dominantes, ${ }^{72}$ denominar o pensamento de Rodrigues Dória e dos autores que partilham desse pensamento em uma relação de sucessão e simultaneidade, ${ }^{73}$ de ideologia proibicionista.

Uma das características formadoras desse conjunto de ideias foi a patologização dos usuários. Sem apresentar evidências, Rodrigues Dória (1986) cita relatos populares em que os usuários crônicos de cannabis, após longos períodos de uso, seriam acometidos por uma caquexia e/ou tísica da maconha. A primeira seria uma espécie de enfraquecimento total das funções vitais e do corpo, já a segunda seria uma descrição popular para o que chamamos hoje de tuberculose. "[...] diz o povo haver uma tísica da maconha, de forma aguda e rápida, exterminando a vida em dois ou três meses." (grifo nosso). ${ }^{74}$

A partir da validação que Ihe foi concedida pela instituição médica, Rodrigues Dória transpõe o ideário popular da época para a ciência, atribuindo efeitos que não foram comprovados, nem mesmo até os dias atuais, aos usos da cannabis. De todo modo, é preciso localizar temporalmente o discurso médico-científico de Rodrigues Dória e da ciência do século XIX e início do XX. José Rodrigues da Costa Dória formou-se em $1882,{ }^{75}$ época em que os ditos homens de letras, principalmente médicos que gozavam de grande prestígio na sociedade, ocupavam os espaços de produção de verdade, e eram marcados pela ideia de que a formação

69 CARVALHO, Jonatas C. de. A emergência da política mundial de drogas: o Brasil e as primeiras Conferências Internacionais do Ópio. Oficina Do Historiador, Porto Alegre, v. 7, n. 1, p. 153-176, 2014, p. 159.

70 LUCENA, José. Os fumadores de maconha em Pernambuco. In: MINISTÉRIO DA SAÚDE. Maconha: coletânea de trabalhos brasileiros. Rio de Janeiro: Oficinas Gráficas do IBGE, 1958, p. 266.

71 SOUZA, Jorge Emanuel Luz de. Op. cit., p.58.

72 ALTHUSSER, Louis. Ideologia e aparelhos ideológicos... Op. cit., p.77.

73 SCHAFER, L; SCHNELLE, T. In: FLECK, Ludwik. Op. cit., p. 13.

74 DÓRIA, José Rodrigues da Costa. Os fumadores de maconha: efeitos e males do vício. In: HENMAN, Anthony; PESSOA JUNIOR, Osvaldo (org.). Op. cit., p.35.

75 SAAD, Luísa Gonçalves. Op. cit., p.12. 
deveria abarcar diversos campos do saber. ${ }^{76}$ Tal fato fica evidente, por exemplo, nos diversos espaços e funções de produção de conhecimento e poder que Rodrigues Dória ocupou, dos quais destacamos o de professor nas Faculdades de Medicina e Direito, o de membro do Instituto Histórico e Geográfico da Bahia, entre outros. ${ }^{77}$

A patologização seguiu seu curso, Rodrigues Dória não estava sozinho, posto se tratar de uma relação de sucessão e simultaneidade. ${ }^{78} \mathrm{Em} 1918$ foi publicado nos Anais paulistas de medicina cirúrgica o texto "Sobre o vício da diamba" do agrônomo Francisco de Assis Iglésias que, apesar da sua formação, teria sido o primeiro a realizar ensaios laboratoriais de modo a comprovar os efeitos psicoativos da cannabis e para isso irá contar com o apoio de médicos como Vital Brazil, Juliano Moreira e outros. ${ }^{79}$ Ao descrever o plantio da cannabis no interior do Nordeste, Iglésias afirmava que o seu uso era determinante na loucura dos usuários. Em seguida, cita e corrobora um esboço apresentado por outro médico, que afirma que entre outros efeitos colaterais, a cannabis poderia levar a estupidez e ao suicídio. ${ }^{80}$

Apesar da emergência de um discurso médico-científico proibicionista fortemente amparado na malha social, nos imaginários e no cenário público, em 1946 Garcia Moreno, um dos primeiros a realizar, em algum grau, uma contra-argumentação, apresentou a contradição da ideologia proibicionista ao associar, especificamente, seu uso com distúrbios mentais. Não obstante, em contra-argumento não conclusivo, Garcia Moreno, que foi diretor do Serviço de Assistência a Psicopatas de Sergipe e que teve sua formação influenciada pelo pensamento de Rodrigues Dória, acaba por atribuir tal hipótese à concentração de THC das plantas.

[...] não vi citados, entre nós, casos de psicoses de longa duração filiadas à etiologia canábica. [...] quando examino meus pacientes, até agora não pude isolar um caso sequer, em que a diamba pudesse ser indigitada como causa dos distúrbios mentais. [...] A impressão que, presentemente, possuo do aspecto psiquiátrico-clínico do maconhismo sergipense e, por analogia, do Nordeste, é que ele ainda não pode entrar, facilmente, para a rubrica das psicoses heterotóxicas da classificação brasileira. Não sei quantas razões existem para o fato. Enquanto não se apurar ou dosar a riqueza da canabina brasileira, julgo que é lícito supor apenas que a razão esteja no baixo poder tóxico de nossa Cannabis sativa. ${ }^{81}$

Para além de expor uma contradição no interior do ideário proibicionista, Garcia Moreno teve seu discurso silenciado e minimizado na comunidade médico-científica. Thomas Kuhn, ao analisar o funcionamento dos paradigmas nas ciências em sua célebre obra $A$ Estrutura das

76 SÁ, Dominichi Miranda de. Op. cit., p.36.

77 DÓRIA, José Rodrigues da Costa. Os fumadores de maconha: efeitos e males do vício. In: HENMAN, Anthony; PESSOA JUNIOR, Osvaldo (org.). Op. cit., p.19.

78 SCHAFER, L; SCHNELLE, T. In: FLECK, Ludwik. Op. cit., p.13.

79 REBOLLEDO, Mauricio Becerra. Fundamentos organicistas e práticas laboratoriais na patologização das drogas no Brasil e no Chile (meados do século XIX ao inicio do século XX). 2015. Dissertação (Mestrado em História das Ciências e da Saúde) - Casa de Oswaldo Cruz, Fiocruz, Rio de Janeiro, p. 243.

80 INGLÉSIAS, Francisco de Assis. Sobre o vício da diamba. In: HENMAN, Anthony; PESSOA JUNIOR, Osvaldo (org.). Op. cit., p.48.

81 MORENO, Garcia. Aspectos do maconhismo em Sergipe. In: HENMAN, Anthony; PESSOA JUNIOR, Osvaldo (org.). Op. cit., p.65. 
Revoluções Científicas de 1962, lembra-nos que, quando as resoluções de quebra-cabeças (problemas científicos) por meio da ferramenta paradigmática se depara com uma anomalia, i.e., um problema não solucionável, a tendência dos adeptos do paradigma é de minimizá-la ou omiti-la. ${ }^{82}$ Por outro lado, Ludwik Fleck, analisando a ciência em contexto anterior ao de Kuhn, aponta que este é um funcionamento próprio do que chama de estilo de pensamento pressupostos que fundamentam a construção do saber no interior de um coletivo de pensamento, que é uma comunidade de cientistas ou disciplina, nesse caso a medicina. Quando os coletivos de pensamento alcançam destaque e passam a ter autoridade científica, fatos resistentes, como a contradição apresentada por Garcia Moreno, tendem a reaparecer, mas são ignorados devido a uma tendência a persistência na tese apresentada pelo grupo diante da contradição, e passam a compor um quadro de detalhes insignificantes que são omitidos ou reinterpretados. ${ }^{83}$ Nesse mesmo sentido apontando tanto por Fleck quanto por Kuhn, ${ }^{84}$ a tese geral apresentada pelos médicos que compuseram a ideologia proibicionista brasileira também desconsiderou estudo realizado no ano 1893 pelo Império Britânico na Índia. Esse estudo tinha como objetivo aferir os impactos do uso da maconha naquela sociedade e apontou que "resultados maléficos praticamente não decorrem do uso moderado de derivados de maconha", 85 esses resultados foram ignorados, nunca tendo sido citados.

Para além da patologização dos usuários de cannabis, a corrente médica proibicionista brasileira, ao pautar a ideologia de combate à cannabis, por diversas vezes buscou associar o seu uso com a criminalidade, retratando os usuários de maconha como criminosos em potencial, ou até alegando de forma explícita que o seu uso levaria inevitavelmente ao cometimento de crimes. Rodrigues Dória dizia que "[o]s embriagados [pela maconha] tornam-se rixosos, agressivos, e vão até a prática de violências e crimes, se não são contidos [...]". ${ }^{86}$ Iglésias afirmava que seu uso levaria a agressividade, "[u]ns ficam em estado de coma, em completa prostração; os outros dão para cantar, correr, gritar; outros ficam furiosos, querem agredir, tornam-se perigosos". ${ }^{87}$ Indo na mesma direção da tese de Rodrigues Dória e de Iglésias, Garcia Moreno parece querer ir além, afirmando que a maconha seria um estimulante usado com frequência por criminosos: "O sentimento de coragem e de exaltação física fornecido pelo tóxico

82 KUHN, Thomas S. A Estrutura das Revoluções Científicas. São Paulo: Editora Perspectiva S.A., 1990, p. $77-92$.

83 FLECK, Ludwik. Op. cit., p.157.

${ }^{84}$ Para uma análise detalhada e comparativa entre o estilo de pensamento de Fleck (1935) e o paradigma kuhniano (1962) ver: CONDÉ, Mauro L. L. Paradigma versus Estilo de Pensamento na História da Ciência. In: FIGUEIREDO, Betânia G.; CONDÉ, Mauro L. L. Ciência, história e teoria. Belo Horizonte: Argvmentvm Editora, 2005, p. 123-146.

${ }^{85}$ SAAD, Luísa Gonçalves. Op. cit., p.4.

86 DÓRIA, José Rodrigues da Costa. Os fumadores de maconha: efeitos e males do vício. In: HENMAN, Anthony; PESSOA JUNIOR, Osvaldo (org.). Op. cit., p.29.

87 IGLESIAS, Francisco de Assis. Sobre o vício da diamba. In: HENMAN, Anthony; PESSOA JUNIOR, Osvaldo (org.). Ibidem, p. 45. 
explica que os malandros recorram a dois ou três baseados, antes da aventura". ${ }^{88}$ Botelho e Pernambuco seguem a mesma linha de Iglésias ao descreverem os efeitos da planta, segundo eles: "[u]ns ficam em completa prostração, outros cantam, gritam, correm, tornam-se agressivos e perigosos". 89 Já Oscar Barbosa é ainda mais fatalista e afirma que: "o abuso da maconha pode ocasionar a idiotia, a loucura transitória ou definitiva e levar o viciado à prática de crimes e até ao suicídio, quando a morte não o surpreenda". ${ }^{90}$

A agressividade, animalidade, ferocidade ou a naturalização do corpo negro como criminoso é uma tônica muito comum do racismo e dos processos de desumanização e, no caso em questão, trata-se de uma ideia fortemente legitimada pelo discurso médico-científico no contexto pós-abolição. O desenvolvimento de uma racionalidade científica que antecede práticas discriminatórias sistemáticas que terão a raça como fundamento, manifestando-se em práticas conscientes ou inconscientes e culminando em desvantagens ou privilégios para indivíduos de acordo com o grupo racial que pertencem, ${ }^{91}$ mostra de forma consolidada a tônica do racismo sistemático, não por acaso, nota-se a articulação do discurso médico-científico com outros ramos de pensamento da vida social brasileira.

Foi dessa forma - agressividade, animalidade, ferocidade e criminalidade - que a cannabis e seus usuários foram representados pelo discurso médico-científico pautado pela ideologia proibicionista. Uma forma institucionalizada entre o final do século XIX e início do século XX que perdura até os dias atuais, inclusive em tons preocupantemente racistas, nos mais diversos discursos sociais, políticos e científicos. Os adeptos da ideologia proibicionista viam na sua efetiva proibição a única solução para esse terrível mal, uma forma de repressão e criminalização dos usuários, as únicas saídas possíveis para conter o 'mal social inoculado como vingança pelos negros escravizados'. Assim, a patologização dos usuários de cannabis e associação com a criminalidade formaram a justificativa racional necessária para sua criminalização e proibição.

O íntimo contato da ciência - que produz seu conhecimento de forma esotérica (interna), com o público mais amplo, letrado e por vezes iniciado, que seria o meio exotérico (externo), ${ }^{92}$ evidencia o funcionamento da influência da sociedade na produção do discurso médico-científico, que não é um ente apartado da malha social, mas um produto forjado no seu interior e que tem com a sociedade uma relação de troca mútua, em regime de organicidade. Ao passo em que o discurso médico-científico busca popularizar suas descobertas e levá-las até os que estão no círculo exotérico, ele também é pressionado pelo meio exotérico para que atenda seus anseios. ${ }^{93}$

\footnotetext{
88 MORENO, Garcia. Aspectos do maconhismo em Sergipe. In: HENMAN, Anthony; PESSOA JUNIOR, Osvaldo (org.). Op. cit., p.61.

89 BOTELHO, Adauto; PERNAMBuCO, Pedro. Vício da diamba. In: MINISTÉRIO DA SAÚdE. Maconha: coletânea de trabalhos brasileiros. Rio de Janeiro: Oficinas Gráficas do IBGE, 1958. p. 28.

90 BARBOSA, Oscar. O vício da diamba. In: MINISTÉRIO DA SAÚDE. Maconha: coletânea de trabalhos brasileiros. Rio de Janeiro: Oficinas Gráficas do IBGE, 1958. p. 43.

${ }^{91}$ ALMEIDA, Silvio Luiz de. Racismo estrutural. Op. cit., p. 22-27.

92 FLECK, Ludwik. Op. cit., p.157.

93 Ibidem, p. 198.
} 
A ideologia proibicionista, forjada no coletivo de pensamento ${ }^{94}$ da medicina, não tinha seu discurso e práticas orientadas por evidências científicas sólidas. Tal discurso era em parte produto social da sua época: um Brasil pós-abolição que temia uma revolta do povo negro nos moldes da Revolução Haitiana e que necessitava de instrumentos de controle social que permitissem ao país controlar uma grande massa de afrodescendentes. Em uma sociedade construída sobre um sistema jurídico positivista, as instituições burocráticas e seus sistemas serviram ao grupo racial dominante, apoiando-se na instituição médica como sua principal fornecedora de subsídios científicos, quando não havia simultaneidade na ocupação de ambos os lugares - produtores de ciência e legisladores, como foi o caso de muitos dos médicos aqui apresentados. Assim, a hierarquia social do Brasil necessitava ser reorganizada após a abolição, a fim de perpetuar a desigualdade entre negros e brancos ${ }^{95}$ e favorecer a manutenção do status quo vigente. Em outras palavras, uma reorganização discursiva pautada na ciência para manutenção da organização social vigente.

A ciência pode, assim como alertou Fleck, influenciar os meios políticos, sociais, culturais e, simultaneamente, ser influenciada pelos mesmos, ${ }^{96}$ motivo pelo qual tanto o discurso que ataca a ideologia proibicionista tal como construída no Brasil, quanto o que busca reforçar-lá coexistem na atualidade, assim como coexistiram no passado aqui descrito. No flanco aberto dos discursos, a ciência e a política, assim como a legislação e a justiça, caminham lado a lado em constante jogo de forças e suporte mútuo.

\section{Considerações finais}

Para além dos atravessamentos e marcas do racismo científico na construção do discurso médico-científico vinculado ao que denominamos de ideologia proibicionista, é necessário considerar que este já surge com fragilidades e atende a interesses dúbios da ideologia ao qual se vincula. Assim, é preciso problematizar o surgimento desse discurso justamente no período em que há uma revolução na produção e uso de fármacos, e ascensão do domínio e posterior monopólio da indústria farmacêutica. Essa sucessão de fatos parece assemelhar-se ao que aconteceu na Colômbia com a chicha, ${ }^{97}$ denominado de "veneno da raça" e "causador de degeneração física e moral", esses foram os argumentos utilizados pelo discurso médico no

\footnotetext{
94 Op. cit., p. 83.

95 SAAD, Luísa Gonçalves. Op. cit., p.52.

96 FLECK, Ludwik. Op. cit., p.157.

97 "[...]bebida ancestral das populações indígenas que habitavam a zona central [da Colômbia] [...] fabricada por meio de um processo de fermentação do milho e fez parte da dieta cotidiana de indígenas e camponeses até a primeira metade do século XX." NOGUERA, Carlos Ernesto. Luta Antialcoólica e Higiene Social na Colômbia, 1886-1948. In: HOCHMAN, G; ARMUS, D. Cuidar, controlar, curar: ensaios históricos sobre saúde e doença na América Latina e Caribe. Rio de Janeiro: Fiocruz, 2004, p.103.
} 
combate ao consumo da chicha na Colômbia, o que acabou resultando na sua substituição pela "higiênica cerveja". ${ }^{98} \mathrm{O}$ caso colombiano pode ser utilizado como possível paralelo para o caso da cannabis no Brasil, em ambos é possível observar o emprego da categoria de degeneração na produção e enunciação do discurso médico-científico, entretanto é necessário reconhecer que, tratam-se de estilos de pensamento e consequentemente coletivos de pensamento ${ }^{99}$ diferentes.

A categoria de degeneração, entendida por Rodrigues Dória e pelos seus sucessores a partir das ideias de Bénédict Morel (1809-1873) e Valentin Magnan (1835-1916) foi fundamental para a tentativa de compreensão que seria empreendida por ele em seu trabalho e, consequentemente, para a formação da ideologia proibicionista. A degeneração pode ser entendida, a partir do pensamento de Morel e Magnan, como um movimento de retrocesso de um estado mais evoluído para um menos evoluído, tal retrocesso se dá devido a diversas causas e, de diferentes maneiras, a depender da época. ${ }^{100}$ As ideias de Morel e Magnan irão inspirar, tempos depois, Cesare Lombroso no desenvolvimento de sua antropologia criminal, ${ }^{101}$ por exemplo. É interessante notar como essa rede de pensamento se constitui; há trocas e influências entre as obras produzidas por essas diferentes correntes de pensamento. Rodrigues Dória mobiliza esse conceito de modo a tentar compreender e propor soluções para os usos da maconha. Em sua concepção, a degeneração congênita seria central na ocorrência do vício, que passa a ser entendido como uma enfermidade social, um problema moral e físico, que atinge todo o corpo social, assim, a degeneração é uma das características dessa enfermidade social, que margeia os limites do conhecimento científico e dos preconceitos morais e raciais da sua época. ${ }^{102}$

Nesse contexto, a eugenia brasileira teve papel fundamental, pois é por meio dela que se cria uma imagem da realidade em que características físicas são determinantes para compreensão do comportamento de determinadas raças, e das medidas públicas que seriam necessárias para extinguir as enfermidades sociais específicas a essas categorias, o que promoveria o avanço e melhoramento de todo o corpo social. ${ }^{103} \mathrm{Na}$ visão dos proibicionistas do pós-abolição, tais medidas favoreceriam também o branqueamento da população brasileira. 0 desenvolvimento da ideologia proibicionista ocorre permeado por essas ideias.

\footnotetext{
98 Op. cit., p.101.

99 FLECK, Ludwik. Op. cit., p.110.

100 SERPA JR., Octavio Domont de. O degenerado. História, Ciências, Saúde - Manguinhos, Rio de Janeiro, v.17, supl.2, p. 447-473, 2010, p. 463. Disponível em: http://dx.doi.org/10.1590/S010459702010000600011. Acesso em: 26 dez. 2020.

101 REBOLLEDO, Mauricio Becerra. Fundamentos organicistas e práticas laboratoriais na patologização das drogas no brasil e no chile (meados do século XIX ao inicio do século XX). 2015. Dissertação (Mestrado em História das Ciências e da Saúde) - Casa de Oswaldo Cruz, Fiocruz, Rio de Janeiro, p. 65.

102 NOGUERA, Carlos Ernesto. Luta Antialcoólica e Higiene Social na Colômbia, 1886-1948. In: HOCHMAN, G; ARMUS, D. Cuidar, controlar, curar: ensaios históricos sobre saúde e doença na América Latina e Caribe. Rio de Janeiro: Fiocruz, 2004, p.101.
}

103 SERPA JR., Octavio Domont de. Op cit. 
Além disso, vale destacar outro contexto que influenciou o processo descrito anteriormente, a ocorrência em paralelo da revolução farmacológica que resultou na expansão da indústria farmacêutica e teve como efeito a consolidação do seu monopólio e a escolha por drogas que pudessem ser sintetizadas em laboratório e que permitissem a separação dos princípios ativos, que após serem transformados em fármacos, seriam utilizados pela medicina no tratamento das doenças. Cabe ressaltar que boa parte dos fármacos tiveram origem em substâncias encontradas na flora, um exemplo emblemático é o ópio, que era utilizado medicinalmente e teve a partícula da morfina isolada a partir dele. ${ }^{104}$ Tal movimento de apropriação de psicoativos pela indústria farmacêutica, como ocorreu com o ópio, compuseram um processo de transformação dos psicoativos em fármacos e, consequentemente, em mercadorias. Estas mercadorias são validadas pelo discurso científico e tornam-se comercializáveis após esse processo. Vale lembrar, uma validação científica que ocorre permeada pelos discursos morais e raciais da época.

Ao trazer tal problematização para a maconha é necessário considerar que a planta teve seu principal princípio ativo, o Tetrahidrocanabinol (THC), isolado somente em 1964 pelo cientista israelense Raphael Mechoulan, ${ }^{105}$ com isso, apesar de o uso medicinal da maconha ter origem milenar, como mencionado no início do presente trabalho, durante a expansão da indústria farmacêutica, esta parece não ter enxergado nela um potencial mercadológico a ponto de buscar transformá-la em produto farmacológico, como ocorreu com outras substâncias como o ópio, que teve seu alcaloide isolado em 1806 e em 1820 já era vendido como morfina na Europa e Estados Unidos. ${ }^{106}$ Isso pode ter acontecido tanto pelo estigma imputado à planta quanto a possíveis dificuldades técnicas em identificar e isolar seus princípios ativos medicinais. ${ }^{107}$ Por outro lado, sabemos que, recentemente, tal movimento em relação ao uso farmacológico da cannabis tem sido retomado, obviamente em outro contexto histórico, com outros coletivos de pensamento, com outros personagens e permeado por outros jogos de poder da cena pública do final do século XX e início do século XXI, muito embora alguns dos principais estigmas contra o povo negro, tal como aqui descritos, permaneçam.

Por quaisquer vias, não se pode perder de vista que havia um direcionamento racial e de classe a ser ordenado no pós-abolição, a saber, separar os produtos farmacológicos "aceitáveis" daqueles oriundos de culturas e hábitos degenerados a serem higienizados, proibidos e "branqueados". Assim, nota-se que a legitimação de uma substância enquanto droga ou fármaco

\footnotetext{
104 ADIALA, Julio Cesar. Drogas, medicina e civilização na primeira República. 2011. Tese (Doutorado em História das Ciências e da Saúde) - Casa de Oswaldo Cruz, Fiocruz, Rio de Janeiro, p. 36.

105 MALCHER-LOPES, Renato; RIBEIRO, Sidarta. Maconha, cérebro e saúde. Rio de Janeiro: Vieira \& Lent, 2007. p. 43.

106 ADIALA, Julio Cesar. Drogas, medicina e civilização... Op. cit.

107 Contudo, cabe salientar que até 1905 haviam anúncios em jornais dos Cigarros Indios, fabricados pela empresa Grimault e importados da França, eram feitos de maconha e indicados para asma, insônia e tosses. CARLINI, Elisaldo Araújo. A história da maconha no Brasil. Jornal Brasileiro de Psiquiatria, Rio de Janeiro, v. 55, n. 4 , 314-317, 2006, p. 316.
} 
é, também, uma condição socialmente imposta, variando de acordo com o contexto. Tal condição socialmente imposta certamente considera o caráter multirracial e pluricultural das sociedades da região latino-americana, construída sob o jugo colonial, do supremacismo branco, e permeada pela crença de que as classificações e os valores da cultura ocidental branca são os únicos, verdadeiros e universais. ${ }^{108} \mathrm{~A}$ suposta superioridade branca tenta definir quem são os grupos racializados, o que podem ou não fazer, ou usar e, a partir do discurso médico, define os caminhos para regular o uso, como da cannabis, por exemplo.

Entretanto, é importante ressaltar que esse discurso é heterogêneo. Assim, em seu interior há correntes de pensamento proibicionistas seculares. Com relação à corrente médicocientífica proibicionista aqui descrita, conclui-se que esta integrou o racismo científico brasileiro, não só partilhando de várias de suas hipóteses, como também elaborando novas hipóteses relacionando raça, criminalidade e os usos da cannabis. O trabalho desenvolvido pela corrente médico-científica proibicionista colaborou na modulação do coletivo de pensamento ${ }^{109}$ do século XIX até a primeira metade do século XX, algumas dessas hipóteses ainda permeiam as correntes proibicionistas na atualidade.

Ademais, é parte fundamental a ser considerada neste quadro a influência do discurso médico ao longo de toda a história das proibições de psicoativos no Brasil, tratamos aqui em especial da cannabis spp. Assim como a planta tem uma relação intrínseca com a história humana, o discurso médico a acompanha há séculos. Como mencionado ao longo deste trabalho, a cannabis spp serviu como medicamento em vários períodos da história humana, estando presente em momentos de extrema relevância para o desenvolvimento da medicina, sendo tradicional, popular e utilizada para o tratamento de uma ampla variedade de enfermidades. Contudo, em dado momento histórico essa planta, que antes era aliada da medicina, passou a ser perseguida, estigmatizada e criminalizada, juntamente com seus usuários.

Compreendendo a ideologia proibicionista enquanto uma imagem da realidade construída a partir das concepções dominantes, ${ }^{110}$ consideramos que as construções científicas imagéticas produzidas por Rodrigues Dória afiliam-se ao eugenismo e ao racismo científico vigente em sua época. Desse modo, a produção de verdade sobre a maconha por parte de Rodrigues Dória deve ser compreendida nesse contexto e sob essas condições e intenções. Mais do que isso, cabe frisar que a atuação de Rodrigues Dória, e dos demais proibicionistas, também favoreceu o silenciamento de pesquisas sobre as possibilidades de utilização da cannabis spp para fins medicinais e conhecimentos populares e tradicionais já existentes. Ao propor a criminalização da maconha, Rodrigues Dória não buscava apenas restringir o acesso ao seu consumo, mas também buscava fornecer ao Estado os elementos necessários para o controle étnico-racial e social dos corpos negros durante o período do pós-abolição. O sistema econômico capitalista em

108 GONZALEZ, Lélia. Lélia Gonzalez: primavera para as rosas negras. São Paulo: UCPA Editora, 2018, p. 311-312.

109 FLECK, Ludwik. Op. cit., p.83.

${ }^{110}$ ALTHUSSER, Louis. Op. cit., p.84. 
uma sociedade racialmente estratificada, que atua de modo a garantir a manutenção do status quo do grupo racial dominante, motivou a construção de um aparato político, cultural, científico e institucional de práticas eugenistas e higienistas sobre grupos racializados, criminalizando-os através do sistema judicial e perpetuando, assim, um dos inúmeros aspectos do racismo estrutural vigente. 


\section{Referências}

ADIALA, Julio Cesar. Drogas, medicina e civilização na primeira República. 2011. Tese (Doutorado em História das Ciências e da Saúde) - Casa de Oswaldo Cruz, Fiocruz, Rio de Janeiro.

ALMEIDA, Silvio Luiz de. Racismo estrutural. São Paulo: Pólen Produção Editorial LTDA, 2018.

ALTHUSSER, Louis. Ideologia e aparelhos ideológicos de Estado. Lisboa: Editorial Presença/Martins Fontes, 1980.

AZEVEDO, Célia Maria Marinho de. Onda negra, medo branco: o negro no imaginário das elites - Século XIX. Rio de Janeiro: Paz e Terra, 1987.

BARROS, André; PERES, Marta. Proibição da maconha no Brasil e suas raízes históricas escravocratas. Periferia, Rio de Janeiro, v. 3, n. 2, p. 1-20, 26 dez. 2011, p. 1-20.

BARBOSA, Oscar. O vício da diamba. In: MINISTÉRIO DA SAÚDE. Maconha: coletânea de trabalhos brasileiros. Rio de Janeiro: Oficinas Gráficas do IBGE, 1958.

BASTOS, Francisco Inácio Pinkusfeld Monteiro et al. (Org.). III Levantamento Nacional sobre o uso de drogas pela população brasileira. Rio de Janeiro: FIOCRUZ/ICICT, 2017.

BOTELHO, Adauto; PERNAMBUCO, Pedro. Vício da diamba. In: MINISTÉRIO DA SAÚDE. Maconha: coletânea de trabalhos brasileiros. Rio de Janeiro: Oficinas Gráficas do IBGE, 1958.

BRASIL. MINISTÉRIO DA SAÚDE. Maconha: coletânea de trabalhos brasileiros. Rio de Janeiro: Oficinas Gráficas do IBGE, 1958.

BUCK-MORSS, Susan. Hegel e Haiti. Novos Estudos - Cebrap. São Paulo, n. 90, p. 131-171, 2011. Disponível em: https://doi.org/10.1590/S0101-33002011000200010. Acesso em: 26 dez. 2020.

CARLINI, Elisaldo Araújo. A história da maconha no Brasil. Jornal Brasileiro de Psiquiatria, Rio de Janeiro, v. 55, n. 4, 2006.

CARNEIRO, Henrique. As necessidades humanas e o proibicionismo das drogas no século XX. Outubro, São Paulo, v. 6, p. 115-128, 2002. Disponível em: http://outubrorevista.com.br/asnecessidades-humanas-e-o-proibicionismo-das-drogas-no-seculo-xx/. Acesso em: 26 dez. 2020.

CARNEIRO, Henrique. Transformações do significado da palavra "droga": das especiarias coloniais ao proibicionismo contemporâneo. In: CARNEIRO, Henrique; VENÂNCIO, Renato Pinto (org.). Álcool e drogas na história do Brasil. São Paulo: Alameda, 2005.

CARVALHO, Jonatas C. de. A emergência da política mundial de drogas: o Brasil e as primeiras Conferências Internacionais do Ópio. Oficina Do Historiador, Porto Alegre, v. 7, n. 1, 2014.

CASTRO-SANTOS, Luiz Antonio de; FIGUEIREDO, Regina Érika Domingos de. Belisário Penna, combatente: um capítulo da história da saúde pública brasileira. Saúde e Sociedade, São Paulo, v. 21, n. 4, p. 848-857, 2012. Disponível em: https://doi.org/10.1590/S010412902012000400005. Acesso em: 26 dez. 2020.

CHALHOUB, Sidney. Cidade Febril: cortiços e epidemias na Corte imperial. Rio de Janeiro: Companhia das Letras, 2017. 
CONDÉ, Mauro L. L. Paradigma versus Estilo de Pensamento na História da Ciência. In: FIGUEIREDO, Betânia G.; CONDÉ, Mauro L. L. Ciência, história e teoria. Belo Horizonte: Argvmentvm Editora, 2005.

DÓRIA, José Rodrigues da Costa. Os fumadores de maconha: efeitos e males do vício. In: HENMAN, Anthony; PESSOA JUNIOR, Osvaldo (org.). Diamba Sarabamba: (coletânea de textos brasileiros sobre a maconha). São Paulo: Ground, 1986.

DUVALL, Chris S. The African roots of marijuana. Durham: Duke University Press, 2019.

ESCOHOTADO, Antonio. Historia general de las drogas. Madrid: Alianza Editorial, 1998.

FARAG, Sayed; KAYSER, Oliver. The Cannabis Planta: Botanical Aspects. In: PREEDY, Victor (ed.). Handbook of Cannabis and Related Pathologies: Biology, Pharmacology, Diagnosis, and Treatment. London: 2017.

FIORE, Maurício. O lugar do Estado na questão das drogas: o paradigma proibicionista e as alternativas. Novos Estudos - CEBRAP, São Paulo, n. 92, p. 9-21. Disponível em: http://dx.doi.org/10.1590/S0101-33002012000100002. Acesso em: 26 dez. 2020.

FLECK, Ludwik. Gênese e desenvolvimento de um fato científico: introdução à doutrina do estilo de pensamento e do coletivo de pensamento. Belo Horizonte: Fabrefactum, 2010.

FRANÇA, Jean Marcel Carvalho. História da Maconha no Brasil. São Paulo: Três Estrelas, 2015.

FREYRE, Gilberto. Casa-grande \& senzala: formação da família brasileira sob o regime da economia patriarcal. São Paulo: Global, 2003.

FREYRE, Gilberto. Nordeste: aspectos da influência da cana sobre a vida e a paisagem do nordeste do Brasil. São Paulo: Global, 2013.

GONTIÈS, Bernard; ARAÚJO, Ludgleydson Fernandes de. Maconha: uma perspectiva histórica, farmacológica e antropológica. Mneme: revista de humanidades, Caicó, v. 4, n. 7, p. 47-3, 2003. Disponível em: https://www.periodicos.ufrn.br/mneme/article/view/164. Acesso em: 26 dez. 2020.

GONZALEZ, Lélia. Lélia Gonzalez: primavera para as rosas negras. São Paulo: UCPA Editora, 2018.

HENMAN, Anthony; PESSOA JUNIOR, Osvaldo (org.). Diamba Sarabamba: (coletânea de textos brasileiros sobre a maconha). São Paulo: Ground, 1986.

INGLÉSIAS, Francisco de Assis. Sobre o vício da diamba. In: HENMAN, Anthony; PESSOA JUNIOR, Osvaldo (org.). Diamba Sarabamba: (coletânea de textos brasileiros sobre a maconha). São Paulo: Ground, 1986.

KUHN, Thomas S. A Estrutura das Revoluções Científicas. São Paulo: Editora Perspectiva S.A., 1990.

LUCENA, José. Os fumadores de maconha em Pernambuco. In: MINISTÉRIO DA SAÚDE. Maconha: coletânea de trabalhos brasileiros. Rio de Janeiro: Oficinas Gráficas do IBGE, 1958.

LUNARDON, Jonas Araujo. Maconha, Capoeira e Samba: a construção do proibicionismo como uma política de criminalização social. Anais do I Seminário Internacional de Ciência Política da Universidade Federal do Rio Grande do Sul, Porto Alegre, 2015.

MALCHER-LOPES, Renato; RIBEIRO, Sidarta. Maconha, cérebro e saúde. Rio de Janeiro: Vieira \& Lent, 2007. 
MORENO, Garcia. Aspectos do maconhismo em Sergipe. In: HENMAN, Anthony; PESSOA JUNIOR, Osvaldo (org.). Diamba Sarabamba: (coletânea de textos brasileiros sobre a maconha). São Paulo: Ground, 1986.

MOTT, Luiz. A maconha na história do Brasil. In: HENMAN, Anthony; PESSOA JUNIOR, Osvaldo (org.). Diamba Sarabamba: (coletânea de textos brasileiros sobre a maconha). São Paulo: Ground, 1986.

NASCIMENTO, Abdias do. O quilombismo: documentos de uma militância pan-africanista. Rio de Janeiro: Fundação Cultural Palmares, 2002.

NOGUERA, Carlos Ernesto. Luta Antialcoólica e Higiene Social na Colômbia, 1886-1948. In: HOCHMAN, G; ARMUS, D. Cuidar, controlar, curar: ensaios históricos sobre saúde e doença na América Latina e Caribe. Rio de Janeiro: Fiocruz, 2004.

REBOLLEDO, Mauricio Becerra. Fundamentos organicistas e práticas laboratoriais na patologização das drogas no brasil e no chile (meados do século XIX ao inicio do século XX). 2015. Dissertação (Mestrado em História das Ciências e da Saúde) - Casa de Oswaldo Cruz, Fiocruz, Rio de Janeiro.

REN, Meng et al. The origins of cannabis smoking: Chemical residue evidence from the first millennium BCE in the Pamirs. Science Advances, Washington, v. 5, n. 6, p. 1-8, 2019. Disponível em: https://advances.sciencemag.org/content/5/6/eaaw1391. Acesso em: 26 dez. 2020.

RODRIGUES, Marcela Franzen. Raça e criminalidade na obra de Nina Rodrigues: uma história psicossocial dos estudos raciais no Brasil do final do século XIX. Estudos e Pesquisas em Psicologia, Estudos e Pesquisas em Psicologia, Rio de Janeiro, v. 15, n. 3, p. 1118-1134, 2015. Disponível em: http://pepsic.bvsalud.org/scielo.php?script=sci_arttext\&pid=S180842812015000300019\&Ing=pt\&nrm=iso. Acesso em: $26 \mathrm{dez} .2020$.

SÁ, Dominichi Miranda de. A ciência como profissão: médicos, bacharéis e cientistas no Brasil (1895-1935). Rio de Janeiro: Fiocruz, 2006.

SAAD, Luísa Gonçalves. Fumo de negro: a criminalização da maconha no Brasil. 2013. Dissertação (Mestrado em História) - Faculdade de Filosofia e Ciências Humanas, Universidade Federal da Bahia, Salvador.

SANTOS, Gislene Aparecida dos. A invenção do "ser negro": um percurso da idéias que naturalizaram a inferioridade dos negros. São Paulo: Pallas, 2002.

SANTOS, Rafael Guimarães dos. Breve panorama etnobotânico sobre a maconha. In: MACRAE, Edward; ALVES, Wagner Coutinho (org.). Fumo de Angola: canabis, racismo, resistência cultural e espiritualidade. Salvador: EDUFBA, 2016.

SERPA JR., Octavio Domont de. O degenerado. História, Ciências, Saúde - Manguinhos, Rio de Janeiro, v.17, supl.2, p. 447-473, 2010. Disponível em: http://dx.doi.org/10.1590/S010459702010000600011. Acesso em: $26 \mathrm{dez} .2020$.

SOUZA, Jorge Emanuel Luz de. Sonhos da diamba, controles do cotidiano: uma história da criminalização da maconha no Brasil republicano. Salvador: EDUFBA, 2015.

SOUZA, Vanderlei Sebastião de. A eugenia brasileira e suas conexões internacionais: uma análise a partir das controvérsias entre Renato Kehl e Edgard Roquette-Pinto, 1920-1930. História, Ciências, Saúde - Manguinhos. Rio de Janeiro, v. 23, supl., p.93-110, 2016. Disponível em: https://doi.org/10.1590/s0104-59702016000500006. Acesso em: 26 dez. 2020. 